\title{
Rock Art and Archaeology - a Short Visit to Zolat el Hammad, Northern Sudan
}

\author{
Friederike Jesse ${ }^{a}$
}

\begin{abstract}
The striking sandstone formation of Zolat el Hammad is located in the southern Libyan Desert, about halfway between the Middle Wadi Howar and El Atrun. The place has been known for its numerous rock engravings for more than a hundred years. Wild and domesticated animals as well as few human figures are depicted. Cattle engravings largely dominate, followed by giraffes and ostriches. In 1997 the first paintings were discovered in a small rock shelter. Very schematic bovids are drawn in red and white colour. However, even though it is one of the most remarkable rock art sites in this part of the Sahara, Zolat el Hammad has never been intensely studied. Observations on rock art and archaeology made during a short stay in $200 \mathrm{I}$ are the basis for presenting an account of the area with the aim of encouraging further research on it.
\end{abstract}

KEY-WORDS: Northern Sudan, Libyan Desert, Zolat el Hammad, rock art, archaeology

\section{INTRODUCTION}

The striking rock formation of Zolat el Hammad, situated about halfway between the Middle Wadi Howar and El Atrun (Fig. I:I), has been known for more than one hundred years. Under the name Zolat el Hammad, the sandstone formation discovered in 1907 by Capt. Coningham is already noted on the map sheet I:250.000 "Jebel Rahib 44-K" from 1908 with the addition "Peculiar pillar-like boulders on N. E. side of Rocky Jebel" (Newbold 1924: 67, the quotation here; Kröpelin 1993: 59). The unusual forms of the sandstone pillars, some reminiscent of animals or human figures, are also referred to in the Arabic name of the site: "Zolat" means rocks or pebbles and "el Hammad" means the praiseworthy (Newbold 1924: 67). The rock art present in the approximately circular area with a diameter of $c .6 \mathrm{~km}$ was described only later (see "A short history of research"). However, Zolat el Hammad was always only afforded

a University of Cologne, Institute of Prehistoric Archaeology, African Archaeology, Jennerstrasse 8, 50823 Köln; e-mail: friederike.jesse@uni-koeln.de; ORCID: 0000-0002-9653-5530 
276 Friederike Jesse
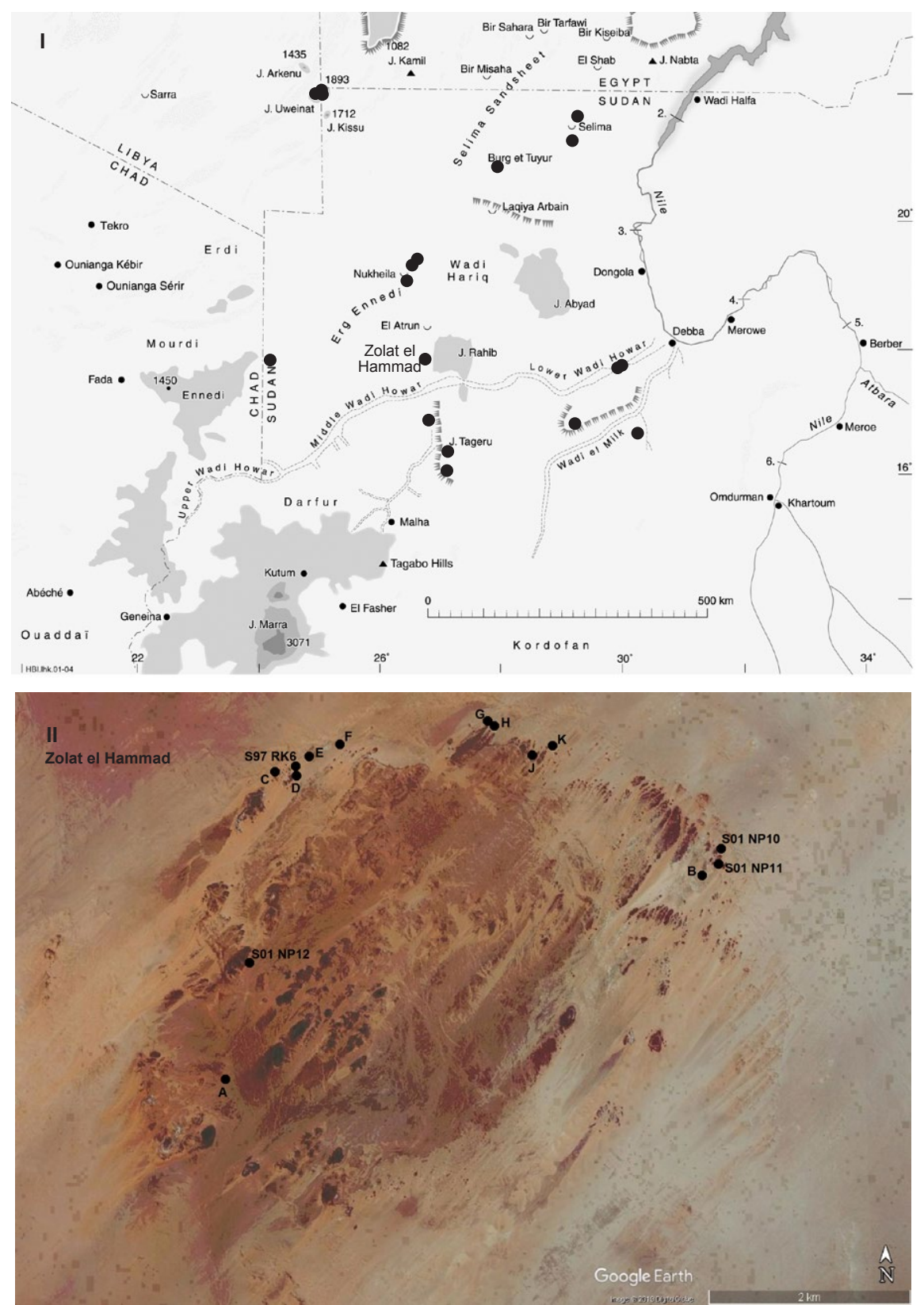

Fig. I. I - Map of the southern Libyan desert showing the location of Zolat el Hammad and further rock art sites (Map Forschungsstelle Afrika); II - The area of Zolat el Hammad indicating the rock art sites (points $\mathrm{A}-\mathrm{K}$ ) and further archaeological observations (Base map Google Earth).

Computer graphics: F. Jesse. 
a short stop for numerous visitors - besides various research expeditions also various tourist groups. A systematic recording of the entire rock art site, already described by the first visitors as extraordinarily rich, has not yet taken place. There is little evidence of other archaeological remains, such as pottery, stone artefacts or other traces of human presence: only Kröpelin (1993: 62) mentions the existence of ring-shaped stone settings. In November 200I, during an excavation campaign of the Cologne research project ACACIA (Arid Climate Adaptation and Cultural Innovation in Africa), the author was able to spend a short stay in Zolat el Hammad for the first and to date only time. The volume dedicated to Michał Kobusiewicz offers a good opportunity to briefly introduce the site's rock art and archaeology by means of the notes and observations made there and to bring Zolat el Hammad back into focus as an object of research.

\section{A SHORT HISTORY OF RESEARCH}

Douglas Newbold was the first European to describe the rock art in Zolat el Hammad (Newbold 1924; 1928). Already in 1917, nomad Howawir had discovered rock art "near a clump of bushes and trees, called Waara el Gilud (also: Wa'ra el Gilud) - "The coppice of the Skins". It was so named, since the Howawir had found the site, "when skinning slaughtered game here" (Newbold 1928: 277). During his very short first stay in 1923, Newbold made some pictures and sketches of the engravings found there (Newbold 1924: 64-67). On another visit in 1927, now together with William Boyd Kennedy Shaw, a more detailed description was possible (Newbold and Shaw 1928; Newbold 1928). "There are represented tailed phallic and plumed men, elephants, giraffes, ostriches, oryx, cattle innumerable, dogs, and several other animals difficult to determine, but possibly including monkeys, addax, rock-rabbits and a lion. There were no camels" (Newbold 1928: 277).

Since then the rock paintings of Zolat el Hammad have been visited again and again. The 11. Deutsch-Innerafrikanische Forschungs-Expedition (DIAFE XI) under Leo Frobenius at the beginning of the I930s was among the numerous other visitors to the striking sandstone formation. However, due to logistical difficulties (water and fuel shortage), the expedition could only stay for a short time in Zolat el Hammad. A sandstorm made the conditions even more difficult and so photos and some quick sketches were made only (Rhotert 1952: 79; see also Almásy 1935: 207-208; 1997: 223). Rhotert (1952), however, provides a quite detailed record of the rock art in Zolat el Hammad and describes the sandstone rock group as "almost strewn with engravings" (Rhotert 1952: 79; original: "mit Gravierungen geradezu übersät").

In the 1980s, geoscientific and archaeological research projects based at the universities of Berlin and Cologne reached the region. During the excavation campaign of the Cologne project Besiedlungsgeschichte der Ostsahara (B. O. S.) at the beginning 
$278 \mid$ Friederike Jesse

of 1984, a longer stop in Zolat el Hammad was possible. Various rock art locations were documented photographically (for pictures see the African Archaeology Archive Cologne $[\mathrm{AAArC}]^{1}$ : search term "Zolat"). Among others, this is the "main engraving site", which was already presented by Newbold (1924; 1928) and Rhotert (1952; Fig. I:II, point $\mathrm{A}^{2}$ ). Site 84/94 was also documented (see below). The rock art lies on the western side of the area of Zolat el Hammad. Here also the main routes run through the southern Libyan desert, among them the famous Darb el Arba'in, the road of 40 days (for an overview see Riemer and Förster 2013: 52-53).

During a geological survey conducted by the Berlin Collaborative Research Centre 69 in 1985 , petroglyphs on the eastern side of Zolat el Hammad were documented (Kröpelin 2004: II4). These had apparently already been discovered by the desert explorer Samir Lama earlier on ${ }^{3}$ (Berger 1997: 8I). Thus two rock art areas can be distinguished: "Zolat el Hammad West", the Waara el Gilud already described by Newbold and Rhotert (Hinkel 1979: 130-131; Kröpelin 1993: 59; Berger 1997: 8I) and "Zolat el Hammad East" (Kröpelin 1993: 59-62; 2004: II4-II6; Berger 1997). On the platform-like surface of the sandstone hill above the rock formations of Zolat el Hammad East, some circular stone settings with diameters around $2 \mathrm{~m}$ were found. These may be remains of human habitation (Kröpelin 1993: 62).

During the field research of the Cologne ACACIA project, Zolat el Hammad was visited several times: In the spring of 1997, for the first time paintings were discovered in a small abri and noted under the site designation S97 RK6 (see below). Further short stays took place in November 200I and between 2003 and 2005 (Jesse et al., 2013: 84-85; for pictures see $\left.\mathrm{AAArC}^{4}\right)$.

\section{THE ROCK ART}

The spectrum of rock art depicted in Zolat el Hammad has already been outlined in the first descriptions (Newbold 1924; 1928; Rhotert 1952) and supplemented by further publications (Kröpelin 1993; 2004; Berger 1997; 1999): wild and domesticated animals as well as human figures. There are a large number of depictions of cattle in a wide variety of forms and designs. In addition to very schematic illustrations (e.g., Rhotert 1952: plate XLIII, 4-7), there are clearly more naturalistic ones, which also show

1 https://arachne.dainst.org/project/afrarchcologne

2 For the mapping of the "main engraving site" the indications given in the archaeological map of Sudan (Hinkel 1979: 130-13I and map) were used.

3 Berger (1997: 8I) mentions the late I940s but this seems to be an error.

4 https://arachne.dainst.org/entity/5061851; arachne.dainst.org/entity/5061852; arachne.dainst.org/ entity/5061848 
the pattern of the coat (e.g., Rhotert I952: plate XLI; AAArC ${ }^{5}$ ). The variety of the horn forms is striking: "There are high or wide open, lyre-shaped, large round horns, arched to the front, steeply standing upwards, short, flat curved horns standing at an obtuse angle to each other or asymmetrically arranged horns"6 (Rhotert 1952: 80, see also Tab. p. I02). Dogs are rarely depicted (Rhotert 1952: Taf. XLV, 3 and Taf. XLVII, I-3). Kröpelin (2004: II4-II5, Fig. II) also mentions goats.

Giraffes clearly dominate the depicted wild animals. Here, too, there are strongly stylised representations (e.g., Rhotert 1952: plate XLIV, I) as well as more naturalistic ones (e.g., Rhotert 1952: plate XLV, 4-5). Petroglyphs showing "seated" giraffes are striking (e.g., Rhotert 1952: plate XLV, I; AAArC7; see also Berger 1997: 84). Occasionally elephants are depicted (Almásy 1935: 208; e.g., Rhotert 1952: plate XLVI, I-4; Kröpelin 1993: 6I, photo I4b), then surprisingly small. Rhotert (1952: 84) therefore assumes that these were depicted from memory or according to indirect information. Ostriches are present, sometimes in the middle of cattle herds (e.g., Kröpelin 1993: 60, also photo I3b; 2004: II5, Fig. I2). At a rather inaccessible place in Zolat el Hammad East engravings of rhinoceroses were discovered. A real herd is depicted together with human figures with strikingly round heads (Kröpelin 2004: II6, also Fig. 16). Long human figures with rounded heads, mostly without arms and depicted in a static posture, are only known from Zolat el Hammad East (Kröpelin 2004: II4-II5). The human representations located in the western part of Zolat el Hammad are clearly different (Newbold 1924; 1928; Rhotert 1952: 82, see also plate XL, 2-3 and plate XLII, 5; $\left.\mathrm{AAArC}^{8}\right)$. More schematic depictions such as sandal-like forms are rare (Rhotert I952: 86, see e.g., plate XLVII, 6).

The engravings are executed quite differently, partly only deliminated by pecked outlines, partly worked out over the entire surface (Rhotert 1952). On the basis of superposition and patina, a certain time depth of the rock engravings is assumed for both areas (Kröpelin 1993: 60). Paintings have so far only been observed at one point, S97 RK6 (see below). These are very schematically depicted bovids in red and white colour. During the author's one and a half day stay in Zolat el Hammad in November 200I, both rock art areas - Zolat el Hammad East and Zolat el Hammad West - were visited (Fig. I:II, points B-K). The engravings seen fit well into the spectrum described above. No systematic recording of the rock art was made, only a photographic documentation took place. In the following, some observations will be briefly presented.

5 https://arachne.dainst.org/entity/6063264

6 Translated from the original quotation: "Es gibt hohe oder breiter offene, lyraförmige, große rund, bogenförmig nach vorn gekrümmte, steil aufwärtsstehende, kurze, flach gebogen in stumpfem Winkel zueinander stehende oder auch unsymmetrisch angeordnete Hörner" (Rhotert 1952: 80).

7 https://arachne.dainst.org/entity/5061848

8 https://arachne.dainst.org/entity/6060322 
$280 \mid$ Friederike Jesse

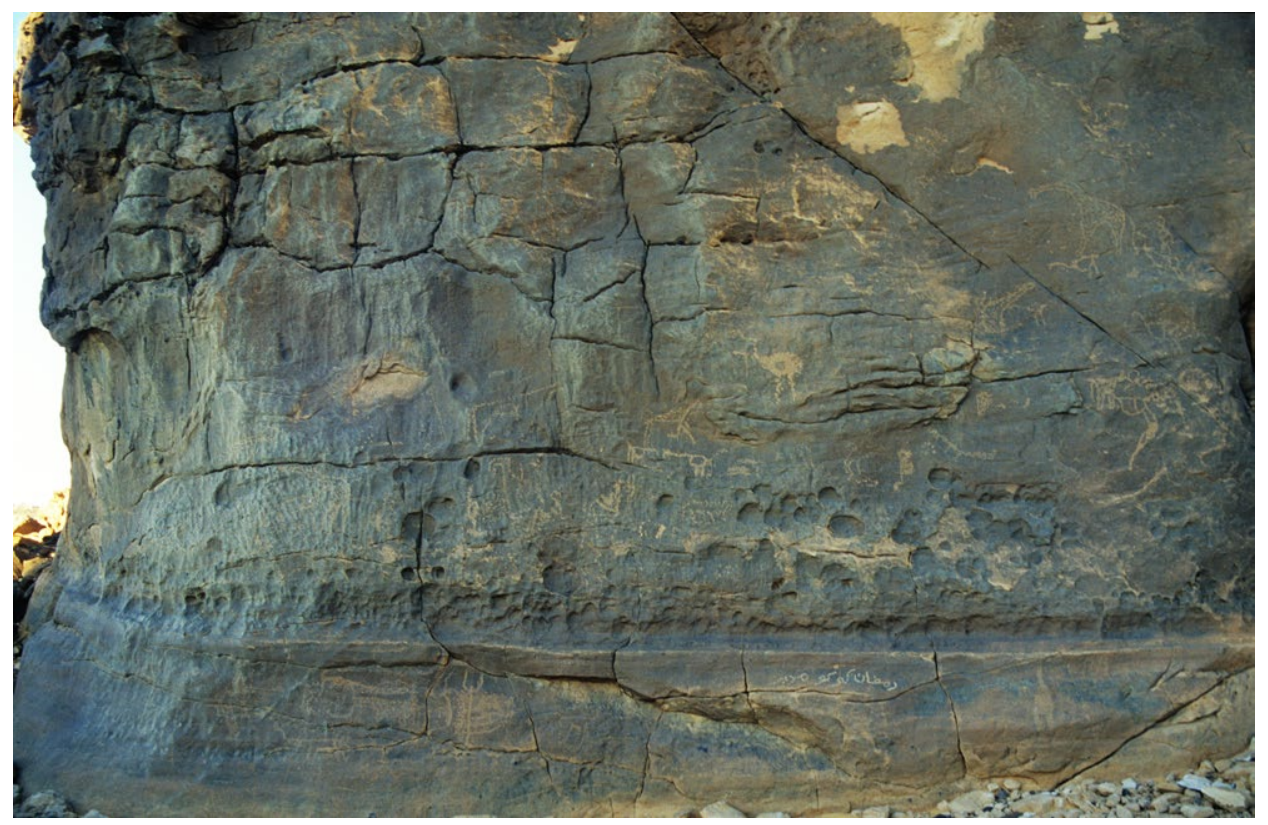

Fig. 2. Zolat el Hammad East, point B. Large frieze with petroglyphs including an Arabic inscription. Photo: F. Jesse.

A larger panel in Zolat el Hammad East (Fig. I:II, point B) shows, beside animal representations (giraffes, bovids, ostriches) also an Arab inscription (Fig. 2). The name "Rahmadan Koko Muhdir" can be read. According to our accompanying NCAM inspector Muawiya Ali El-Tayeb, this might be a person coming from the Nuba Mountains as "Koko" is a common name there for the eldest son.

In Zolat el Hammad West, engravings were documented at various places (Fig. r:II, points $\mathrm{C}-\mathrm{K})$. The engravings were made on different surfaces - vertical as well as horizontal ones. Often they are veritable friezes, but also single engravings were observed. Higher rocks were also used. On an isolated large sandstone block (Fig. I:II, point E), engravings were found on the eastern side showing among other things giraffes, bovids with long horns, an elongated human figure and other only badly recognizable engravings. (Fig. 3:A). A large herd of cattle is depicted within a larger frieze together with other animals such as goats (Fig. I:II, point F; Fig. 4). Superposition indicates that this place was visited again and again. Only about $150 \mathrm{~m}$ south a frieze with at least two giraffes was discovered in a rather high position. Very schematic engravings of cattle were seen on the northern side of a stone block (Fig. I:II, point H; Fig. 3:B). On a horizontal surface near a small rock shelter (Fig. I:II, point J) the representation of an insect-like animal was discovered next to giraffe representations consisting purely 

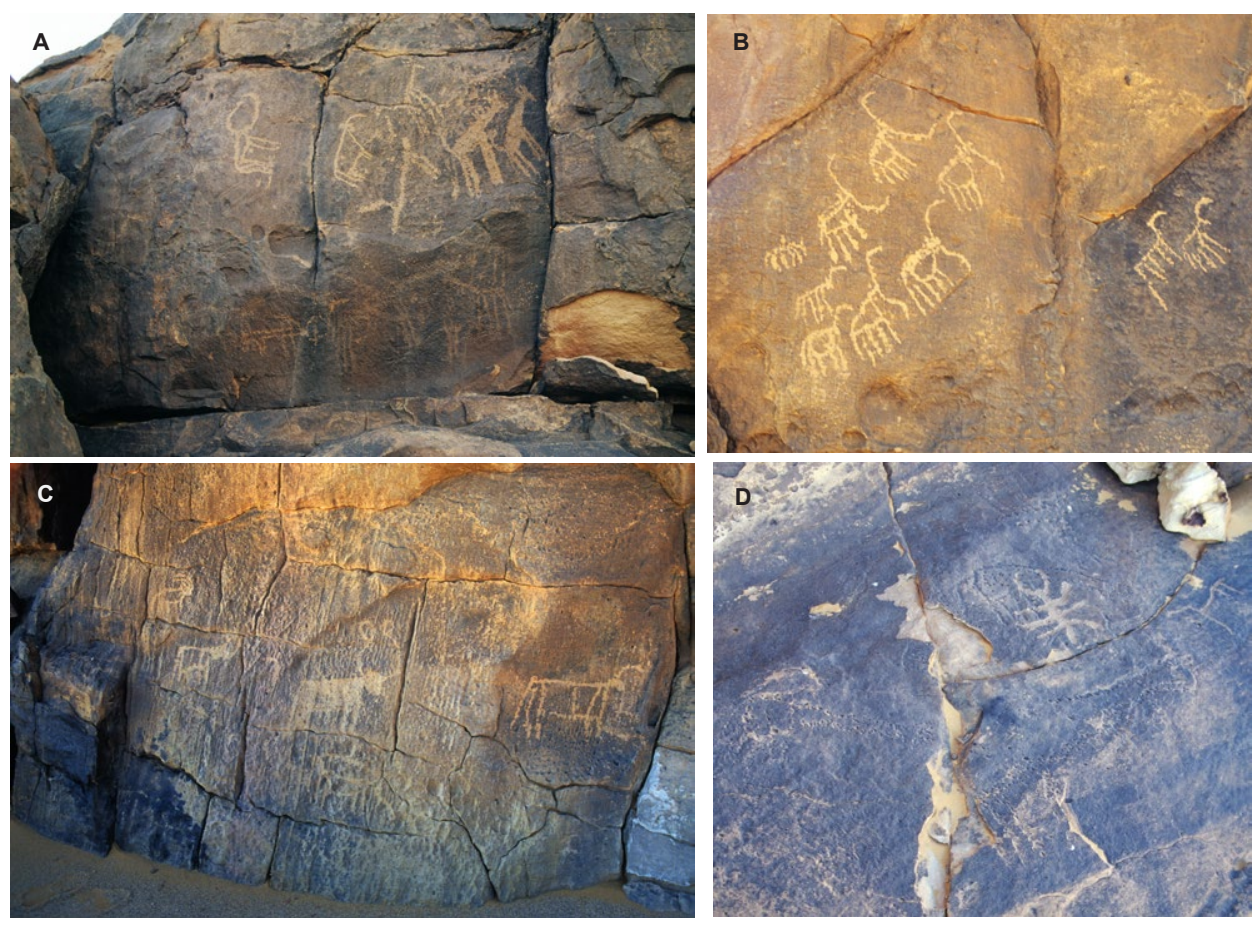

Fig. 3. Zolat el Hammad West. A - Petroglyphs at point E; B - Petroglyphs at point H; C - Petroglyphs at point K; D - Petroglyphs at point J. Photo: F. Jesse.

of dotted lines (Fig. 3:D). At point K (Fig. I:II) gazelles respectively antelopes (possibly Oryx?) were found as well as cattle with pronounced horn deformation (Fig. 3:C). This can best be classified in the category of lyre-shaped horns (Rhotert I952: IO2, table), but this representation is much more elaborate than the examples mentioned there. On the eastern side of a large stone block (Fig. r:II, point D) giraffes, bovids, a human figure, goats and dogs are engraved (Fig. 5). Directly in front of it lay a block chipped off from this stone, which was also densely engraved with giraffes on the chipped side.

\section{FURTHER ARCHAEOLOGICAL OBSERVATIONS - THE SITES}

Although rock art has always been the focus of the various visits to Zolat el Hammad, some archaeological sites have also been described during the short stays within the framework of the excavation campaigns of the Cologne projects B. O.S. and ACACIA (Fig. r:II). These are listed here in chronological order of discovery. 
$282 \mid$ Friederike Jesse

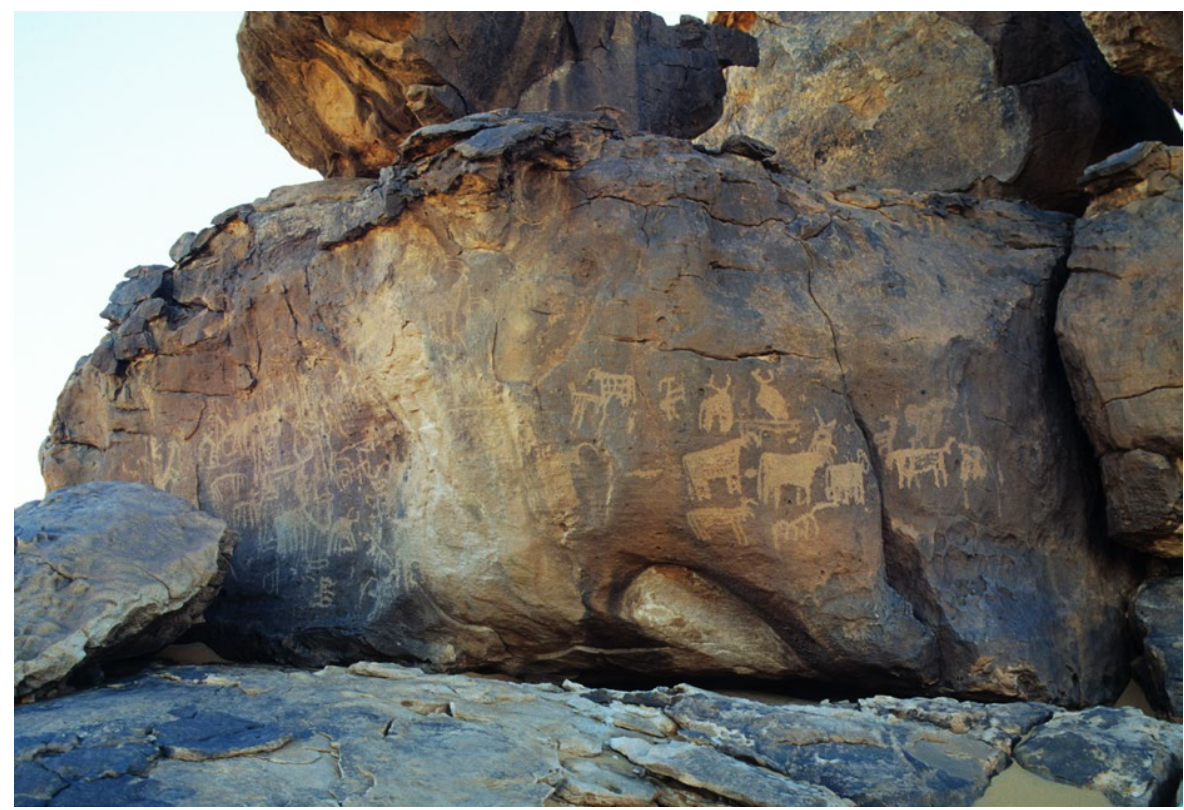

Fig. 4. Zolat el Hammad West. Large frieze with different animals among others a cattle herd at point F. Photo: F. Jesse.

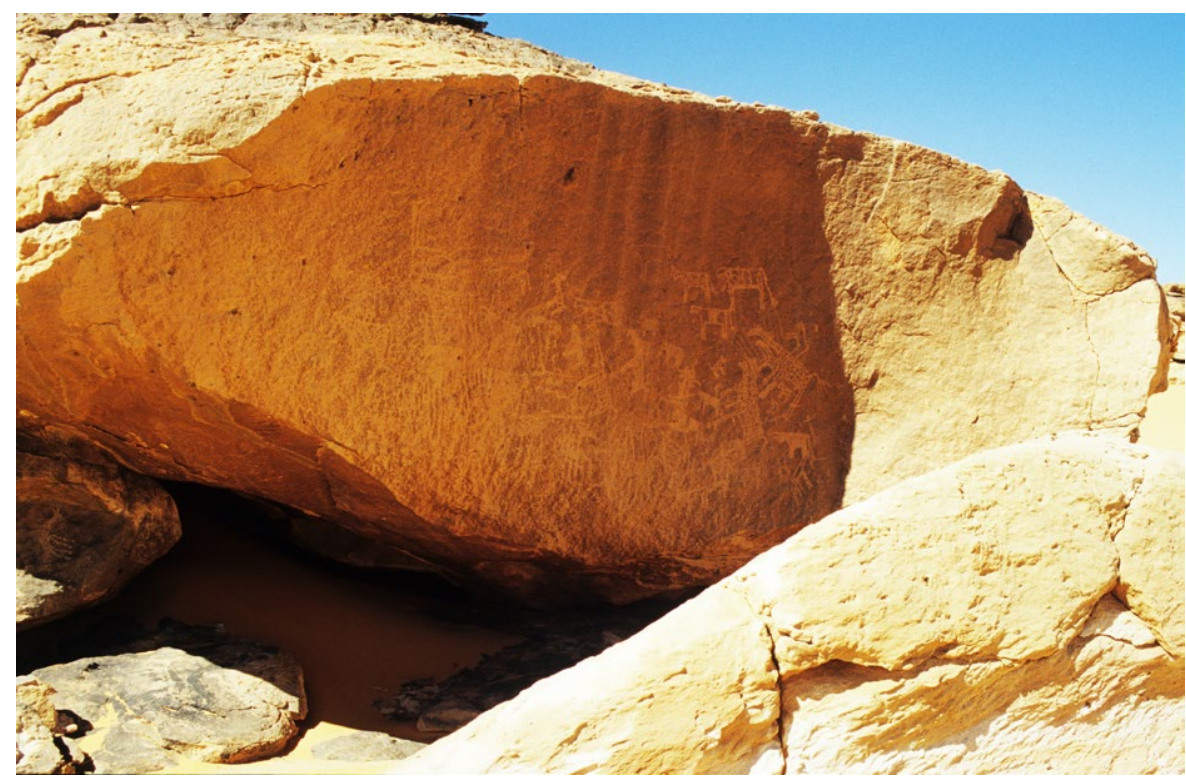

Fig. 5. Zolat el Hammad West. Engravings at point D. Photo: F. Jesse. 


\section{Zolat el Hammad 84/94}

In 1984, an extended loose artefact scatter discovered on a playa-like sediment near the long known rock engravings of Zolat el Hammad (Fig. I:II, point A) was recorded as site 84/94 ( $\left.\mathrm{AAArC}^{9}\right)$. Among the stone artefacts, which are mainly made of coarser and fine-grained quartzite, some segments were recorded. A few pieces of pottery were found, among them sherds with a Dotted-Wavy-Line pattern $\left(\mathrm{AAArC}^{10}\right)$. On the east side of the hills, a small cave without sediment was discovered, in which some "younger" sherds were lying, among them a rim sherd with a kind of herringbone pattern $\left(\mathrm{AAArC}{ }^{11}\right)$.

\section{S97 RK6}

At the beginning of March 1997, a small shelter located on a promontory between the northern boulders of Zolat el Hammad was discovered. (Fig. r:II; Fig. 6:A) The shelter extends over about $3 \times 3 \mathrm{~m}$ and has in it very schematic representations of bovids in red and white colour (Fig. 6:B). Engravings are also present. Pottery with fine quartz temper as well as unretouched stone artefacts were observed.

During the stay in November 200I, in between the sandstone formations of Zolat el Hammad East, flakes and much eroded pottery were observed at many places. At one place, however, a denser artefact scatter justified a site documentation (S01 NP10).

\section{S01 NP10}

The open air site with a loose artefact scatter extends over an area of about $80 \times 50 \mathrm{~m}$. Decorated and undecorated pottery was observed. All sherds were very worn and rounded and heavily tempered with quartz. Among the decorative patterns there were horizontal rows of dots impressed with rocker technique. For the production of stone flakes, a brown silicified sandstone was used as well as quartzite of ochre colour, little chalcedony and quartz. Upper and lower grinding stones were observed as well as animal bones (e.g., bovid tooth lamella fragments).

\section{S01 NP11}

This is a small, very flat shelter filled with sandy sediment, which does not appear to be of great depth. A stone post in the entrance of the shelter had two fainted engravings on its left side. Animals are represented. It was, however, not possible to further identify them. Inside the shelter a few flakes of quartzite (some with retouch) were found as well as a few bone splinters and pieces of ostrich eggshell. One half of a lower

\footnotetext{
9 https://arachne.dainst.org/entity/6060322

10 https://arachne.dainst.org/entity/6064266

11 https://arachne.dainst.org/entity/6060987
} 
284 Friederike Jesse
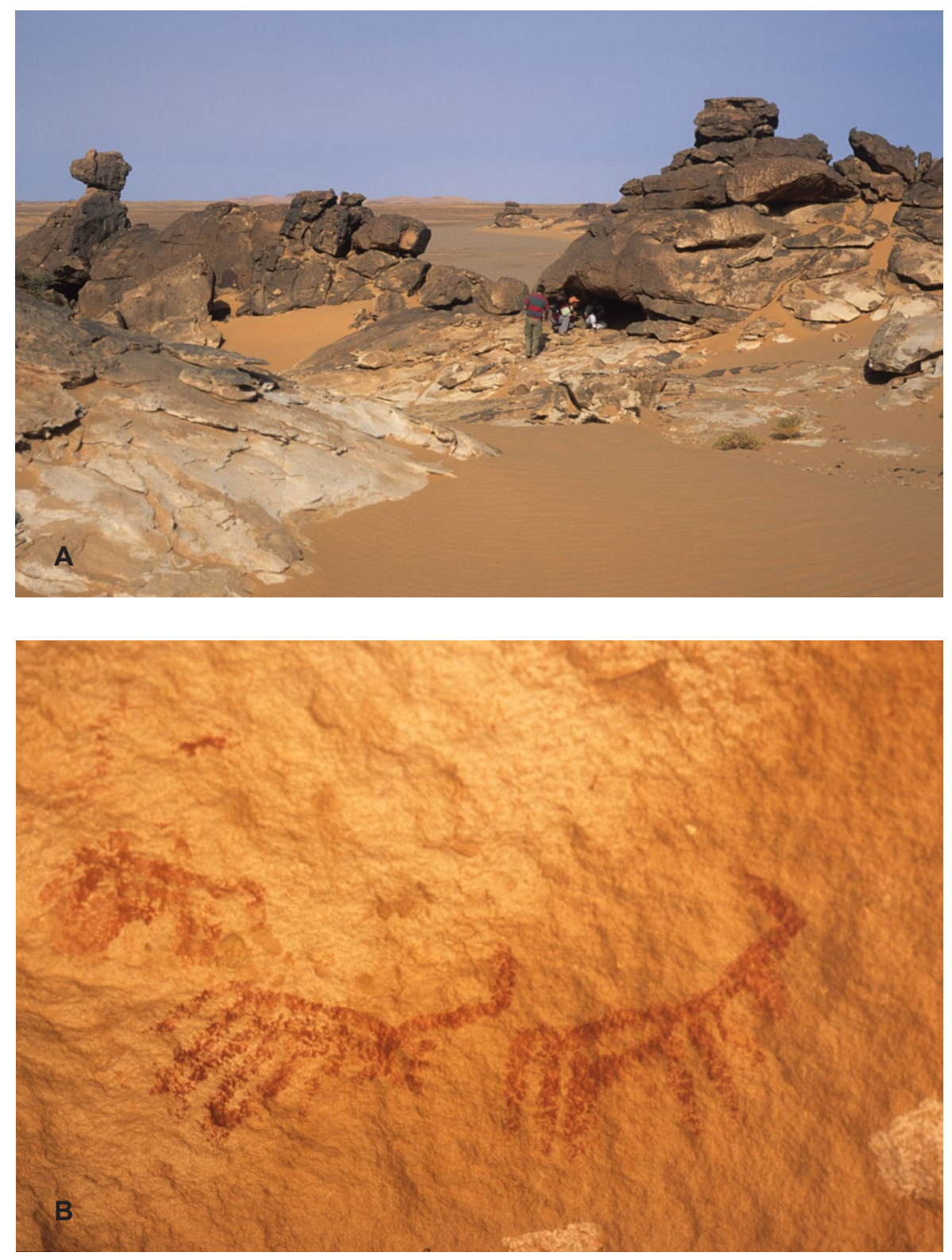

Fig. 6. Site S97 RK6. A - Overview of the site;

$\mathrm{B}$ - Schematic paintings of bovids in red colour.

Photo: R. Kuper. 


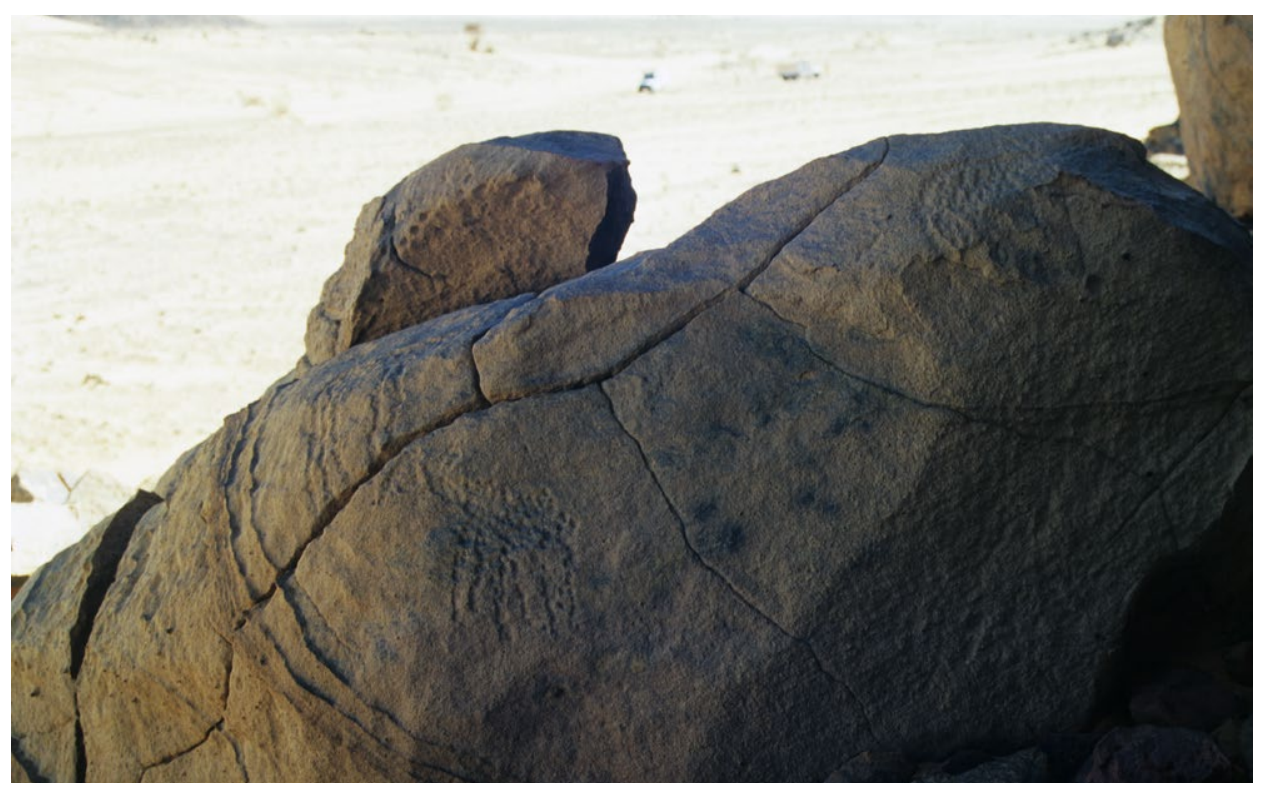

Fig. 7. The petroglyphs at site S01 NP12. Photo: F. Jesse.

grinding stone made of a highly micaceous granitoid lay in front of the shelter. Large flakes mostly made from a brown fine-grained quartzitic sandstone and partly with edge retouch were present. Only few quartz flakes were observed. Two hammerstones, one made of quartz, as well as one core made of a bright quartzite and one upper grinder were also recorded.

\section{S01 NP12}

On the western bank of a valley through which the Darb el Arba'in runs, a small rock shelter was discovered. The place offers a perfect view over the valley where some acacias grow and thus also over the Darb el Arba'in. Therefore the shelter might have been used as a poste de guetteur, a guard. Three pecked petroglyphs representing animals (among them one giraffe) were found on a stone which borders the shelter to the southeast (Fig. 7). Unretouched lithic artefacts were observed.

\section{CONCLUDING REMARKS}

In a nutshell, the spectrum of rock engravings depicted at Zolat el Hammad includes domesticated and wild animals as well as human figures. A striking feature of the cattle depictions is the diversity of the horn forms, which can be seen as an expression 
$286 \mid$ Friederike Jesse

of the importance of cattle for prehistoric groups, similar to the sometimes careful depiction of coat patterns. Within the group of wild animals, giraffe representations dominate. The unusual round-headed human figures in Zolat el Hammad East are so far unique in the Libyan Desert (Kröpelin 2004: II6; for the figures also Berger 1999). So far no camel representation has been found, which gives an indication of the chronological position of the rock art. The engravings in Zolat el Hammad East and West are different from a stylistic point of view as the animals and figures are differently worked. However, a much more detailed recording should take place for verification and refinement of this statement. Most engravings are found at places which can easily be reached, and only seldom are friezes at high altitudes. The few paintings at site S97 RK6 are remarkable. In the southern Libyan desert engravings are much more numerous, e.g., in Jebel Tageru (Newbold 1928) or Lower Wadi Howar (Kröpelin 2004; Jesse 2005).

Different time horizons for the rock art of Zolat el Hammad can be recognised on the basis of patina and superposition. Due to their patina, the rhinoceroses, together with the round-headed human figures, are probably among the oldest representations in Zolat (Kröpelin 2004: II6). In the light of the numerous depictions of cattle, the bulk of the engravings was certainly made by cattle herders. These were present in the Wadi Howar region since the end of the 5 th millennium BC. Pastoral groups are attested up to the 2nd millennium BC (Jesse and Keding 2007; Jesse et al., 2013). The lack of camel representations also indicate that Zolat el Hammad was obviously no longer frequented after the onset of today's aridity during the 2 nd millennium BC. Beyond the rock art itself, due to a lack of diagnostic finds, the archaeological observations made so far are not sufficient to clearly identify phases and patterns of human use. A longer research visit with a comprehensive documentation not only of the rock art but also of the archaeological sites in the whole area of Zolat el Hammad would certainly provide more information here.

\section{REFERENCES}

Almásy, L. E. 1935(1934). Ismeretlen Szahara (Unknown Sahara). Budapest, Franklin Társulat.

Almásy, L. E. 1997. Schwimmer in der Wïste. Auf der Suche nach der Oase Zarzura. Innsbruck, Haymon.

Berger, F. 1997. Report about a Petroglyph Site at Zolat el Hammad in the Libyan Desert, Northern Sudan. In S.-A. Pager (ed.), Rock Art Research - Moving into the Twenty-First Century, 80-93. Okahandja (Namibia). Occasional SARARA Publication No. 4, Southern African Rock Art Association.

Berger, F. 1999. The humans from Zolat el Hammad (Sudan) a status report. Cahiers de l'Association des Amis de l'Art Rupestre Saharien (AARS) 5: 5-7.

Hinkel, F. W. 1979. The Archaeological Map of the Sudan II. The Area of the South Libyan Desert. Berlin, Akademie-Verlag. 
Jesse, F. 2005. Rock Art in Lower Wadi Howar, Northwest Sudan. Sahara I6: 27-38.

Jesse, F. and Keding, B. 2007. Holocene Settlement Dynamics in the Wadi Howar Region (Northern Sudan) and the Ennedi Mountains (Chad). In O. Bubenzer, A. Bolten and F. Darius (eds), Atlas of Cultural and Environmental Change in Arid Africa, 42-43. Köln. Africa Praehistorica 2I.

Jesse, F., Keding, B., Lenssen-Erz, T. and Pöllath, N. 2013. 'I hope your cattle are well': Archaeological Evidence for Early Cattle-centred Behaviour in the Eastern Sahara of Sudan and Chad. In M. Bollig, M. Schnegg and H.-P. Wotzka (eds), Pastoralism in Africa. Past, Present and Future, 66-Io3. New York-Oxford, Berghahn.

Kröpelin, S. 1993. Zur Rekonstruktion der spätquartären Umwelt am Unteren Wadi Howar (Südöstliche Sahara / NW-Sudan). Berlin. Berliner Geographische Abhandlungen 54.

Kröpelin, S. 2004. New petroglyph sites in the Southern Libyan Desert (Sudan-Chad). Sahara I5: III-II7.

Newbold, D. 1924. A Desert Odyssey of a Thousand Miles. Sudan Notes and Records 7: 43-92.

Newbold, D. 1928. Rock pictures and archaeology in the Libyan Desert. Antiquity 2: 26I-29I.

Newbold, D. and Shaw, W. B. K. 1928. An Exploration in the South Libyan Desert. Sudan Notes and Records II: IO3-I94.

Riemer, H. and Förster, F. 20I3. Ancient desert roads: Towards establishing a new field of archaeological research. In F. Förster and H. Riemer (eds), Desert Road Archaeology in Ancient Egypt and Beyond, 19-58. Köln. Africa Praehistorica 27.

Rhotert, H. 1952. Libysche Felsbilder. Ergebnisse der XI. und XII. Deutschen Inner-Afrikanischen ForschungsExpedition (DIAFE) 1933/1934/I935. Darmstadt. 
